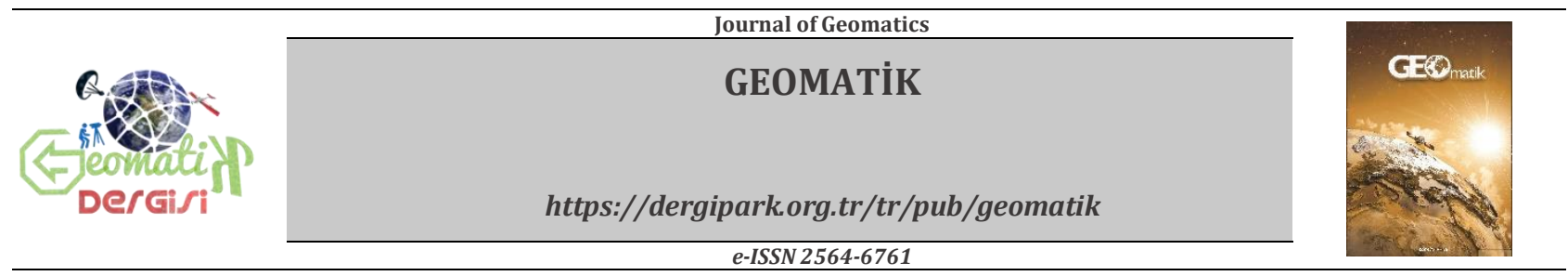

\title{
CBS ve AHP yöntemi yardımıyla Kayseri İli Örneğinde rüzgâr enerji santrallerinin yer seçimi
}

\author{
Tuğrul Urfalı*1®, Abdurrahman Eymen² ${ }^{(1)}$ \\ ${ }_{1}^{1}$ Tokat Gaziosmanpașa Üniversitesi, Tokat M.Y.O., Mimarlık ve Șehir Planlama Bölümü, Tokat, Türkiye \\ ${ }^{2}$ Erciyes Üniversitesi, Mühendislik Fakültesi, Harita Mühendisliği Bölümü, Kayseri, Türkiye
}

Anahtar Kelimeler
Yenilenebilir Enerji
RES
CBS
ÇKKV
Kayseri

ÖZ

Dünya çapında eși benzeri olmayan bir hızla gelișen kentleșme süreci, nüfusun hızlı artıșı ve yükselişe geçen enerji ihtiyacıyla birlikte yenilenebilir enerji kaynaklarına olan ihtiyaçta büyük ölçüde artıș göstermektedir. Yenilenebilir enerji kaynakları içerisinde dünyanın birçok bölgesinde üretilebilen, çevreye zarar vermeyen ve ticari açıdan en elverişli enerji türlerinden birisi de rüzgâr enerjisidir. Rüzgâr Enerji Santralleri (RES), sürdürülebilir enerji projeleri için enerji üretmede en uygun yöntemler arasındadır. 2022 yılına gelindiğinde dünyada enerji ihtiyacının \%12'sinin rüzgâr enerjisinden karşılanacağı tahmin edilmektedir. Bu çalışmada Kayseri ilinde rüzgâr enerji santrallerinin uygun sahalara kurulabilmesi için literatür araştırması sonrasında gerekli olan 12 ana kriter belirlenmiștir. Kriterlerin önem sıralamasını belirlemek için Çok Kriterli Karar Verme (ÇKKV) tekniklerinden biri olan Analitik Hiyerarşi Prosesi (AHP) yöntemi kullanılmıştır. Kriterlerin önem dereceleri belirlenirken uzman görüşleri AHP yöntemi ile değerlendirilmiş; rüzgâr hızı, rüzgâr kapasitesi ve yükseklik kriterleri en önemli 3 kriter olarak belirlenmiștir. Belirlenen kriterlerin konumsal analizleri Coğrafi Bilgi Sistemi (CBS) yazılımı kullanılarak yapılmıştır. Analiz sonuçları ve AHP yöntemi ile belirlenen önem sıralaması birleștirilerek Kayseri ilinde kurulabilecek RES için potansiyel uygun sahalar belirlenmiștir. Kayseri ili kapsamında rüzgâr enerjisi için var olan bu potansiyelin kullanılıp, en ekonomik en verimli şekilde değerlendirilmesi gerekmektedir. Bu amaçla çalışmanın gelecekte kurulacak RES projeleri için yol gösterici olması hedeflenmektedir.

\section{Site selection of wind power plants in the Example of Kayseri with the help of CBS and AHP Method}

Keywords
Renewable Energy
WPP
GIS
MCDM
Kayseri

\begin{abstract}
The need for renewable energy sources increases greatly with the urbanization process, which has been developing with an unprecedented speed throughout the world, the rapid increase of the population and the requirements for rising energy. Wind energy is one of the most commercially available types of energy that can be produced in many regions of the world, which does not harm the environment and is among the renewable energy sources. Wind Power Plants (WPP) are among the most suitable methods of generating energy for sustainable energy projects. By 2022, it is estimated that $12 \%$ of the energy need in the world will be met by wind energy. In this study, 12 main criteria that are necessary after the literature research have been determined in order to establish WPP in the appropriate areas in Kayseri. The Analytical Hierarchy Process (AHP) method, which is one of the Multiple Criteria Decision Making (MCDM) techniques, was used to determine the importance order of the criteria. Expert opinions were taken while determining the importance of the criteria and the wind speed, wind capacity and elevation criteria were determined as the 3 most important criteria. Spatial analysis of the determined criteria was done by using Geographic Information System (GIS) software. By combining the analysis results and the order of importance determined by the AHP method, potentially suitable sites were determined for WPP that can be established in Kayseri. Within the scope of Kayseri province, it is necessary to use this potential for wind energy and evaluate it in the most economical and efficient way. For this purpose, it is aimed that the study will be a guide for WPP projects to be established in the future.
\end{abstract}




\section{GíRiş}

Tüm dünyada nüfusun hızlı artışı ile orantılı olarak enerjiye duyulan ihtiyaçta her geçen gün artmaktadır. Bugün dünyadaki enerji ihtiyacının yüzde 80'inden fazlası fosil yakıtlar kullanılarak üretilmektedir. Fosil yakıtların kullanılması, küresel ısınmaya büyük etkisi olan sera gazlarının başında gelen karbondioksit $\left(\mathrm{CO}_{2}\right)$ salınımının ortaya çıkmasındaki en büyük etkendir. Uluslararası Enerji Ajansı'na göre, fosil yakıtların yanmasından kaynaklanan dünyadaki toplam $\mathrm{CO}_{2}$ salınımları 1973'ten 2015'e \%108 oranında artış göstermiştir (Messaoudi ve ark, 2018; IEA, 2017).

Fosil yakıtların sınırlı olması ve çevreye verdiği zararların önüne geçilememesi, insanları bu kaynakları daha verimli kullanma konusunda yeni arayışlara itmiş ve enerji açığının kapatılması için alternatif enerji kaynaklarına yönelim başlamıştır (Memduhoğlu ve ark. 2014). Bu yönelim yenilenebilir enerji kaynaklarına (güneş, hidro, rüzgâr, jeotermal, gelgit, biyokütle, dalga vb.) olan ihtiyacı ortaya çıkarmıştır. Yenilenebilir enerji, tüketilmesine oranla daha hızlı bir şekilde yeri doldurulan enerji kaynaklarından elde edilen enerji olarak ifade edilir. (Şimşek, 2014; Vaysman ve ark, 2019).

Türkiye Avrupa ile Asya kıtaları arasındaki geçitte yer alan jeopolitik konumu sayesinde Avrasya enerji ticaretinde önemli bir yere sahiptir. Enerji koridoru olarak hizmet vermenin yanı sıra, artan kentsel nüfus, yerleşim alanlarının yeniden yapılandırılması ve gelişmekte olan sanayileşme nedeniyle Türkiye enerjiye ihtiyaç duyan bir ülkeye dönüşmüştür. Bu dönüşüm doğal olarak yeni enerji kaynaklarına olan ihtiyacı ortaya çıkarmaktadır. Yeni enerji kaynakları ihtiyacına ek olarak, Türkiye Avrupa Birliği (AB) adaylığı için halen görüşmelere devam etmektedir. AB, 2030 yılına kadar enerjisinin $\% 27$ 'sini yenilenebilir enerji kaynaklarından elde etmeyi hedeflemektedir. $\mathrm{Bu}$ nedenle enerji kaynaklarının fosil yakıtlardan yenilenebilir enerji kaynaklarına kayması Türkiye'nin katılım sürecinde düzenleyici yüklerini azaltacaktır. Daha fazla yenilenebilir enerji, Türkiye'nin sera emisyonlarını azaltmasını ve ithal enerjiye daha az bağımlı olmasını sağlayacaktır. (Çildir \& Bayraç, 2017; Atici ve ark, 2015).

Yenilenebilir enerji kaynakları içerisinde Dünya'nın her yerinde bolca bulunabilen, düşük maliyetli, temiz, en gelişmiş ve ticari açıdan en elverişli enerji türlerinden birisi de rüzgâr enerjisidir. Bu nedenle rüzgâr enerjisinin kullanımı son yıllarda hem Dünya'da hem de Türkiye'de giderek artan oranda ilgi görmektedir (Özşahin \& Kaymaz, 2013). Yenilenebilir enerji kaynaklarından rüzgâr, diğer geleneksel enerji üretim araçlarına kıyasla, rekabetçi enerji maliyeti ve dünyada hemen hemen her bölgede rüzgâr kaynaklarının bulunması nedeniyle yüksek oranda tercih edilmektedir (T.R. Ayodele ve ark, 2018).
Rüzgâr enerjisinden yararlanma süreci çok eski dönemlere dayanmaktadır. Yelkenli gemiler ve yel değirmenleri rüzgâr enerjisini kullanan en eski teknolojilerdir. Teknolojinin gelişmesiyle birlikte rüzgârdan daha verimli şekilde yararlanılmaya başlanılmıştır. Bu noktada rüzgâr santralleri, ülkelerin enerji ihtiyaçlarını karşılamak için yöneldikleri önemli bir alternatif enerji kaynağ haline gelmiştir. Sürdürülebilir enerji projeleri için rüzgâr enerji santralleri (RES) en uygun enerji üretim yöntemlerinden biri olarak ifade edilmektedir (Şimşek, 2014).

Dünyada 100 'den fazla ülkenin rüzgâr enerjisi ile elektrik üretimi yaptığı bilinmektedir. Dünyada üretilen toplam rüzgâr enerjisinin yaklaşık \%29'unu üreten Çin bu alanda en büyük paya sahiptir. Çin her geçen gün hızla büyüyen sanayisi, yoğun nüfusu ve buna bağlı olarakta her geçen gün artan enerji ihtiyacı sebebiyle, yenilenebilir enerji kaynaklarına büyük yatırımlar yapmış ve rüzgâr enerjisinde ilk sırada yerini almıştır. Çin'den sonra gelen Amerika Birleşik Devletleri ile Almanya dünyada rüzgâr enerjisi üretiminde önde gelen ülkeler olarak görülmektedir. Türkiye bu sıralamada 11'inci sırada yer almaktadır. Avrupa ülkeleri arasında ise 6'ncı sırada gelmektedir (Can \& Yücel, 2019). Şekil 1'de Türkiye'nin 2019 yılı kurulu güç dağılımına bakıldığında \%8,32 ile rüzgâr enerjisinin önemli bir paya sahip olduğu görülmektedir.

Türkiye'nin rüzgâr enerjisi potansiyelinin, yer seçimi çalışmalarının artması, yatırımcıların doğru yerlere yönlendirilmesi ve devlet destekli projeler ile mevcut konumundan daha üst sıralara yükseleceği düşünülmektedir (Can \& Yücel, 2019).

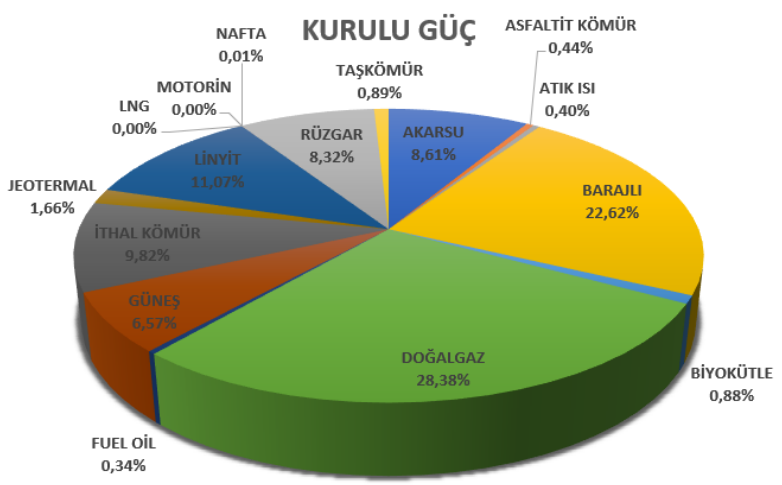

Şekil 1. Türkiye 2019 yılı kaynak bazlı kurulu güç dağılımı (TEİAŞ,2019) (Elektrik port, 2020)

Rüzgâr enerji santrallerinin yer seçimi analizlerinde eğim, yükseklik, arazi kullanım kabiliyeti, koruma alanları, su alanları yerleşim merkezleri gibi birçok konumsal etkenin birlikte analiz edilmesi gerekmektedir. Son dönemde hızla gelişen ve kullanım alanı artan, farklı meslek gruplarının bir arada kullandığı coğrafi bilgi sistemleri, rüzgâr enerjisi alanında da sıklıkla tercih edilir durumdadır (Heimiller \& Haymes, 2001). CBS sadece RES projesi için değil, diğer yenilenebilir enerji uygulamalarında da başarılı bir şekilde 
kullanılmaktadır (Uyan, 2013; Sadeghi ve Karimi, 2017). Çeşitli konumsal kriterleri göz önüne alıp kriterlerin önem sırasına göre en uygun alanı seçmek, çevresel etkiler ve ekonomik açıdan maksimum fayda elde etmek için önemlidir. Özellikle ekonomik olarak RES projelerinin maliyetlerinin oldukça yüksek olmasından dolayı santraller yapılmadan önce projelerin fizibilite çalışmalarının yapılması büyük önem taşımaktadır (Said, Akil, \& Muzakir, 2019; Bennui ve ark, 2007). Rüzgâr enerjisinden yararlanma potansiyeli yüksek sahaları bulmak için belirlenen karar kriterlerinin birlikte değerlendirilmeye ihtiyacı vardır. Çok kriterli karar verme teknikleri (ÇKKV) bu karmaşık problemlerde kullanılabilecek en iyi yöntemdir (Sadeghi ve ark, 2017). ÇKKV'nin coğrafi konum bileșeni ile kullanılması klasik ÇKKV tekniklerinden ayrılmasına neden olmaktadır. Konumsal CKKKV'de her bir seçeneğin hem coğrafi konumu hem de her kriter için değeri gereklidir. Bundan dolayı konumsal karar problemlerinde Coğrafi Bilgi Sistemleri (CBS) ve ÇKKV teknikleri birlikte kullanılır. (Öztürk \& Kılıç, 2010).

Literatürde CBS ve ÇKKV tekniklerinin bir arada kullanıldığı çalışmaların fazlasıyla olduğu görülmektedir. Latinopoulos ve Kechagia (2015), rüzgâr çiftliği projelerinde uygun sahaları seçmek için CBS ve ÇKKV yöntemini birlikte kullanmıştır. Villacreses ve ark. (2017), Ekvator bölgesinde rüzgâr santralleri kurmak için uygun alanları CBS ve ÇKKV yöntemlerini kullanarak belirlemiştir. Uyan (2013), Türkiye'de Karapınar bölgesinde güneș enerji santralleri (GES) için uygun alanları belirlemede (AHP) ve CBS'yi birlikte kullanmıştır. Özşahin ve Kaymaz (2013) Hatay ilinde RES'lerin yapım yeri seçiminde CBS destekli ÇKKV yöntemi kullanarak farklı kaynaklardan elde ettikleri verileri değerlendirmiş̧lerdir. 15 farklı kriterle yapılan analizde, Hatay'ın RES yapımı için orta (\% 45.19) ve iyi (\% 25.64) duyarlılık düzeyinde olduğu tespit edilmiştir. Bunun yanında, uygunluk açısından zayıf (\% 1.33) arazilerin de çok az yer kapladığ görülmüștür. Memduhoğlu ve ark. (2014) yaptıkları çalışmada, rüzgar türbinlerinin konumlandırılmasinda en uygun alanın ortaya konması amacıyla belirlerdikleri kriterleri AHP yöntemi ile ağırlıklandırmış daha sonra CBS-ÇKKV kullanarak en uygun potansiyel alanı tespit etmiştir. Can ve Yücel (2019) çalışmalarında Çanakkale ilini çalışma alanı olarak belirlemiş, CBS ve AHP kullanarak RES için uygun yer tespiti yapmışlardır. Sadeghi ve Karimi (2017) yaptıkları çalışmada, İran'ın Tahran kentinde rüzgar tribünleri ve güneş enerji santralleri için potansiyel uygun alanları ÇKKV ve CBS kullanarak bulmuşlardır. Atici ve ark. (2015) yaptıkları çalışmada, RES için uygun sahaları CBS tabanlı ÇKKV tekniğini kullanarak tespit etmişlerdir.

$\mathrm{Bu}$ çalışmada ÇKKV yöntemi kullanılarak Kayseri ilinde mevcut duruma göre rüzgâr enerji santrallerinin yer seçimine etki eden kriterler incelenmiștir. Kriterlerin belirlenmesinde yapılan literatür taramasının yanında Erciyes Üniversitesi
Harita Mühendisliği, Çevre Mühendisliği Bölümü öğretim üyeleri, kamu kurumları ve özel sektörden uzmanlar ile yapılan görüșmeler sonucunda meteorolojik, altyapı, arazi kullanımı ve topoğrafya ve çevresel kriterler olmak üzere 4 ana başlık altında toplam 12 alt kriter belirlenmiştir. Kriterlerin ağırlıkları ve birbirlerine göre önem derecesi belirlenirken 4 uzman AHP ikili karşılaştırma tablosunu doldurmuş ve sonrasinda bu tabloların ortalaması alınarak ortalama kriter matrisine göre ağırlıklar ve önem derecesi belirlenmiştir. AHP yöntemiyle belirlenen ağırlıklar ve CBS ile üretilen konumsal analiz haritaları bir araya getirilerek Kayseri ili için RES kurulumunun yapılabileceği potansiyel alanlar belirlenmeye çalışılmıştır.

\section{MATERYAL ve METHOD}

CBS belirlenen kriterlere göre yapılan konumsal analizlerin sonuçlarının görselleştirilmesinde karar vericiye yardımcı olmaktadır. Yer seçiminde uygun olmayan seçeneklerin elenip, uygun sahaların belirlenmesinde konumsal analizler kullanılmaktadır. CBS'nin karar destek sistemi konumsal analizlerin ÇKKV teknikleriyle birleştirilmesi sonucunda başarılı olmaktadır.

Bu çalışmada kullanılan metodoloji Şekil 2'de gösterilmektedir. İlk olarak, ilgili kriterler tanımlanmış ve kriterlere göre gerekli veriler elde edilmiștir. Daha sonra CBS tarafında yeniden sınıflandırma haritaları üretilmiştir. ÇKKV sürecinde ise, kriterlerin ağırlıkları AHP yöntemi kullanılarak hesaplanmıştır. Son olarak konumsal CBS analizleri sonucu elde edilen kriterlerin haritaları ağırlıklarına

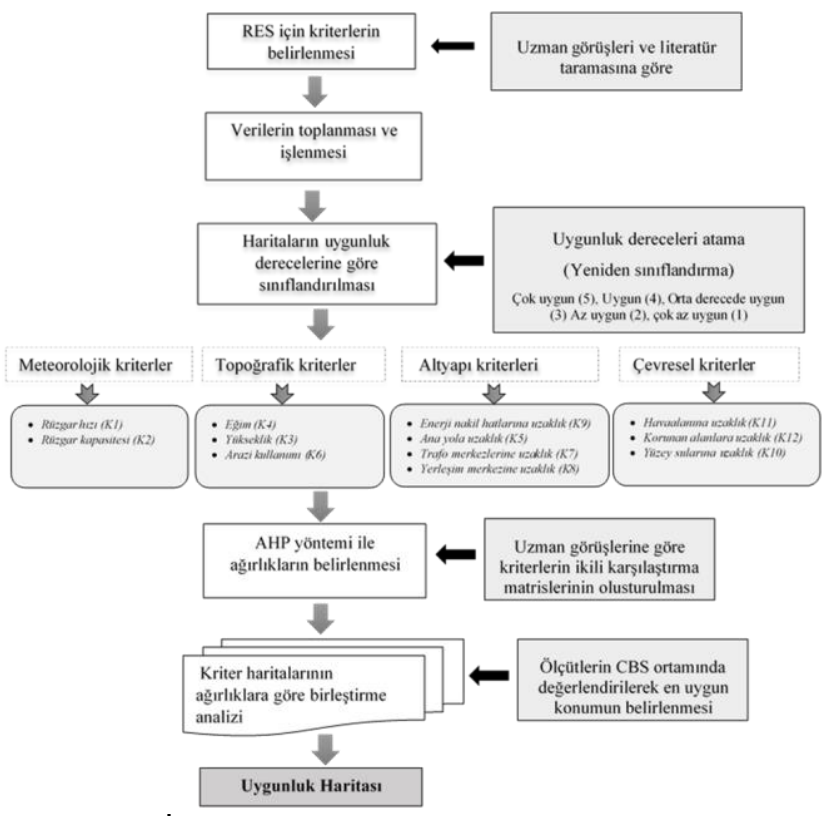

Şekil 2. İş akış şeması göre işleme sokularak uygunluk sonuç haritası elde edilmiştir

\subsection{Calıșma Alanı}

Kayseri, İç Anadolu'nun güney bölümü ile Toros dağlarının birbirine yaklaştığı yerde Orta Kızılırmak 
bölümünde yer alır. Doğu ve kuzeydoğusu Sivas, kuzeyi Yozgat, batısı Nevşehir, güneybatısı Niğde, güneyi ise Adana ve Kahramanmaraș illeri ile çevrilidir. İl de, İç Anadolu Bölgesi'nin tamamında olduğu gibi, bozkır iklimi hüküm sürer. Yazlar sıcak ve kurak, kışın ise soğuk ve yağış̧ geçer. Kayseri 37 derece 45 dakika ile 38 derece 18 dakika kuzey enlemleri ve 34 derece 56 dakika ile 36 derece 58 dakika doğu boylamları arasında bulunmaktadır. Kayseri, elverişli ulaşım ve enerji olanakları ve zengin yeraltı kaynaklarının yanı sıra sanayisi de gelişmiş illerdendir (T.C. Kültür ve Turizm Bakanlığı, 2020) (Şekil 3).

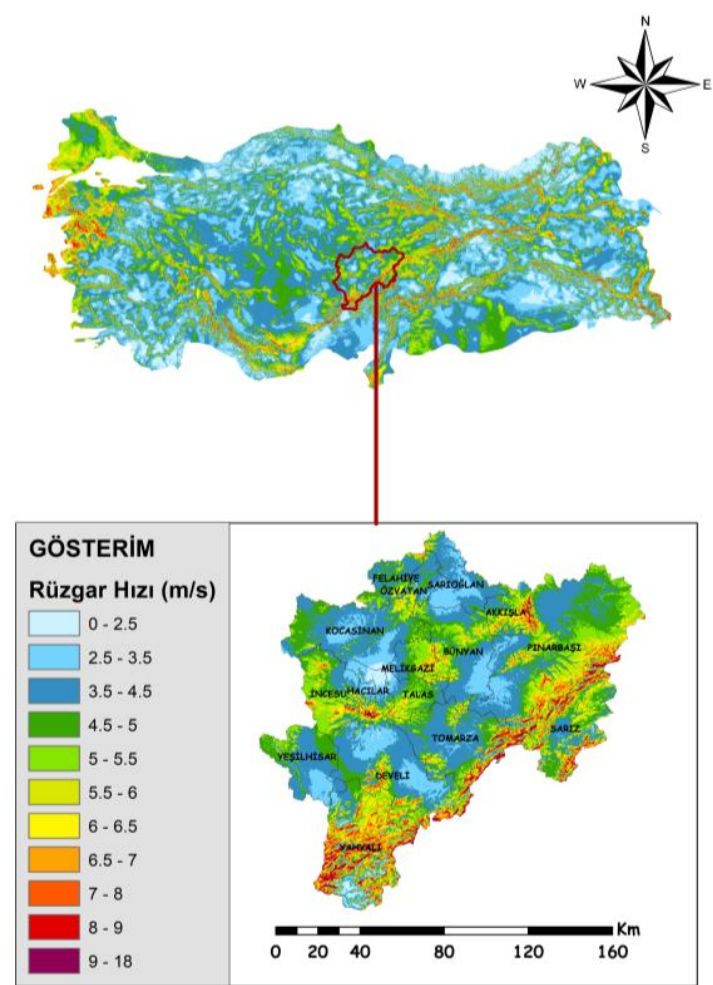

Şekil 3. Çalışma alanı

Çalışma alanı olarak seçilen Kayseri ilinde rüzgâr enerji santrali alanı için en uygun yer seçim çalışması gerçekleştirilecektir. Çalışma alanı olarak Kayseri seçilirken rüzgâr enerji potansiyelinin yüksek olması önemli rol oynamıştır. T.C. Enerji ve Tabii Kaynaklar Bakanlığı Yenilenebilir Enerji Genel Müdürlüğü verilerine göre Türkiye'de illere göre kurulabilecek RES'lerin toplam alanı $22.834,85 \mathrm{~km}^{2}$, toplam kurulu gücü ise 114.174,08 MW'tır. Kayseri bu gruplandirmada $377,06 \mathrm{~km}^{2}$ toplam alana ve $1.855,28$ MW potansiyel güç kapasitesiyle 18. sırada yer almaktadır (Tablo 1). Türkiye rüzgâr enerjisi birliği tarafından 2018'de yayınlanan rapora göre Kayseri RES kurulu güç sıralamasına göre $264 \mathrm{MW}$ ile 7. sırada yer almaktadır (TUREB, 2018) (YEGM, 2019).

\subsection{Analitik Hiyerarşi Süreci (AHP)}

Literatürde en çok tercih edilen çok kriterli karar verme (CKKV) tekniklerinden biri olan Analitik Hiyerarşi Prosesi (AHP), ilk olarak 1968 ylında
Myers ve Alpert ikilisi tarafından ortaya atılmış ve Saaty tarafindan 1980 yllında bir model olarak geliștirilmiștir. AHP ön fizibilite, çalıșma öncesi planlama ve proje önceliklendirme çalışmalarında sıklıkla kullanılmaktadır. AHP'nin kullanım alanlarına bakıldığında enerji, eğitim, çevre, sanayi, inşaat kamu kaynaklarının planlanması, stratejik planlama, sağlık gibi birçok alanda tercih edilen bir yöntem olduğu görülmektedir.

Tablo 1. İllere Göre Kurulabilecek RES'lerin Güç Kapasiteleri (YEGM, 2019)

\begin{tabular}{|l|l|l|l|}
\hline Sira & İl Adı & $\begin{array}{l}\text { Toplam } \\
\text { Kurulu Güç } \\
(\mathrm{MW})\end{array}$ & $\begin{array}{l}\text { Toplam } \\
\text { Alan } \\
\left(\mathrm{km}^{2}\right)\end{array}$ \\
\hline 1$)$ & Balıkesir & 13.827 & 2.765 \\
\hline 2$)$ & Çanakkale & 13.013 & 2.603 \\
\hline 3$)$ & İzmir & 11.854 & 2.371 \\
\hline 4$)$ & Manisa & 5.302 & 1.060 \\
\hline 5$)$ & Samsun & 5.222 & 1.045 \\
\hline 6$)$ & Muğla & 5.171 & 1.034 \\
\hline 7$)$ & Tekirdağ & 4.627 & 925 \\
\hline 8$)$ & İstanbul & 4.177 & 835 \\
\hline 9$)$ & Bursa & 3.882 & 776 \\
\hline 10$)$ & Mersin & 3.531 & 706 \\
\hline 11$)$ & Edirne & 3.470 & 694 \\
\hline 12$)$ & Hatay & 3.414 & 683 \\
\hline 13$)$ & Kırklareli & 3.079 & 616 \\
\hline 14$)$ & Tokat & 3.002 & 600 \\
\hline 15$)$ & Aydın & 2.524 & 505 \\
\hline 16$)$ & Ordu & 2.276 & 455 \\
\hline 17$)$ & Kahramanmaraş & 2.072 & 414 \\
\hline 18$)$ & Kayseri & 1.885 & 377 \\
\hline 19$)$ & Konya & 1.860 & 372 \\
\hline 20$)$ & Sivas & 1.642 & 328 \\
\hline
\end{tabular}

AHP'de ikili karşılaştırma metodu kullanılarak kriterler arasındaki önem derecesi ve kriterlerin ağırlıkları belirlenmektedir. Bu ağırlıklara göre karar verici "Hangisini seçeceğiz?" veya "En iyisi hangisidir?" sorularına yanıt bulmuş olacaktır (Haliloğlu \& Odabaş, 2018) (Öztürk \& Kılıç, 2010).

AHP ile ağırlıkların bulunmasında, ilk olarak hiyerarşik yapı oluşturularak problemin amacı, kriterleri ve alternatifleri belirlenir. Daha sonra kriterler için ölçütlerin ikili kıyaslamaları yapılır ve bunun sonucunda kriterlerden hangisinin önemli olduğu belirlenir. Saaty tarafından oluşturulmuş 1-9 ölçekli değerlendirme tablosu ile karşılaștırma yapılır. Son olarakta kriterlerin ağırlıkları ve tutarlılık oranı hesaplanır. Tutarlılık oranının 0.10 dan büyük çıkması durumunda değerlerin tutarsız olduğu anlaşlır ve ikili karşılaştırma matrisleri tekrardan kontrol edilir.

Tutarlılık oranını hesaplamak için ikili karșılaştırma matrisinin tutarlılı indeksi (CI) 0.13 olarak hesaplandı (1).

$C I=\frac{(\lambda \max -n)}{(n-1)}$ 


$$
C R=\frac{C I}{R I}
$$

Tutarlılık oranı endeksini (CR) bulmak için RI (tesadüfilik göstergesi) Saaty'nin tesadüfilik göstergesi tablosundan 12 kriter için 1.53 olarak alınmış ve 0,08 olarak hesaplanmıștır (2). Tutarlılık oranı 0.10 'un altında ise değerlendirmelerin yeterli bir tutarlılık gösterdiği kabul edilmektedir. Eğer tutarlılık oranı 0.10 'un üstünde ise ikili karşılaştırmalar tekrar gözden geçirilir (Öztürk \& Kılıç, 2010).

\section{BULGULAR}

\subsection{Kriterler ve Uygunluk Sinıfları}

Çalışma alanı olarak seçilen Kayseri ili için, rüzgâr enerji santrallerinin yer seçiminde etkili olan olan kriterler Tablo 2'de gösterilmektedir. Bu veri katmanlarından arazi eğimi, arazi kullanımı, rüzgâr hızı, rüzgâr kapasitesi ve arazi yüksekliği gibi katmanlar raster yapıda kullanılmıştır. Kayseri rüzgâr hızı haritası Kayseri rüzgâr enerji potansiyel atlasından sayısallaştırılarak elde edilmiştir. Kayseri rüzgâr enerji potansiyel atlasına bakıldığında rüzgâr hızının en az 6,5 m/s olması, rüzgâr kapasitesinin ise en az \%30 olan alanların seçilmesi gerektiği görülmüştür. (YEGM, 2019).

Tablo 2. Çalışmada Kullanılan Kriterler

\begin{tabular}{l}
\hline Kriterler \\
\hline Rüzgâr Hızı (K1) \\
Rüzgâr Kapasitesi (K2) \\
Yükseklik (K3) \\
Eğim (K4) \\
Ana Yola Uzaklık (K5) \\
Arazi Kullanımı (K6) \\
Trafo Merkezlerine Uzaklık (K7) \\
Yerleşim Merkezine Uzaklık (K8) \\
Enerji Nakil Hatlarına Uzaklık (K9) \\
Havaalanına Uzaklı (K10) \\
Yüzey Sularına Uzaklı (K11) \\
Korunan Alanlara Uzaklık (K12) \\
\hline
\end{tabular}

RES alanları genellikle koruma altındaki alanlara ve yerleşim merkezlerine uzak, trafo merkezlerinin ve iletim hatlarının da üzerinde olmayacak șekilde yakın olmalıdır (Baban ve ark.,2001). Ayrıca, karayolu ağına yakın olması önem arz etmektedir. Çünkü rüzgâr tribünlerinin inşa edilmesi sırasında kolaylık olması açısından karayolu ağına yakın alanlar tercih edilmelidir. Eğim en fazla \%20 olmalı, yükseklikte Kayseri için en az $1000 \mathrm{~m}$ olmalıdır (Bennui ve ark., 2007).

\subsubsection{Meteorolojik kriterler}

Rüzgâr hızı (K1) kriteri için, ülkemiz de $30 \mathrm{~m}$ yükseklikteki rüzgâr hızları RES yatırımları için ekonomik olmadığından dolayı $50 \mathrm{~m}$ yükseklikteki rüzgâr hızları alınmıştır. Şekil 4'te Türkiye rüzgâr enerjisi potansiyeli atlası (REPA) verilmiștir. Rüzgâr hızı faktörü de RES yatırımları için en önemli kriterlerden birisidir. Rüzgâr hızına göre belirlenen bu faktör, REPA'nın $50 \mathrm{~m}$ yükseltideki kapasite faktörü dağılımı haritasından elde edilmiștir. Rüzgâr kapasite faktörü (K2) rüzgâr hızı ile paralel bir dağılım göstermektedir.

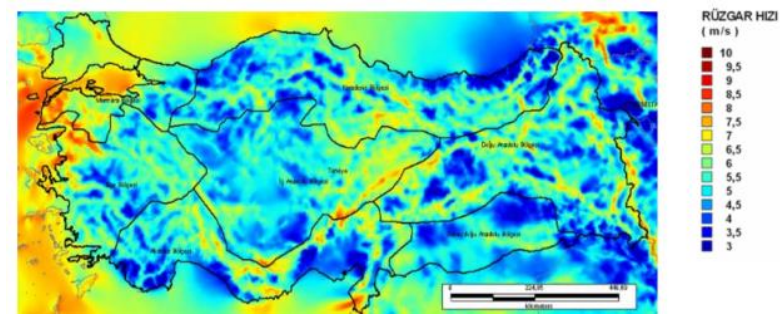

Şekil 4. Türkiye Rüzgâr Hız Dağılımı Haritası (50 m) (YEGM, 2019)

\subsubsection{Altyapı kriterleri}

RES'lerin kurulum yerleri seçiminde yol hatlarına olan uzaklıkları da (K5) değerlendirmeye alınmaktadır. Santraller inşa edilirken maliyet açısından santralin yapılacağı yere ulaşmak önemli olduğu için bu kriter değerlendirilmiştir. RES'lerin kurulum yeri seçiminde dikkat edilmesi gereken faktörlerden birisi de enerji nakil hatlarına olan uzaklıktır(K9). RES'ler yapılırken enerji nakil hatları üzerine kurulmamalıdır (Baban ve ark.,2001). Bununla birlikte enerji nakil hatlarına yakın olmayan yerlerde kurulum ekonomik olamayacağı için çok uzak alanlarda tercih edilmemektedir. Trafo merkezleri enerjinin dönüștürüldüğü alanlardır ve enerji nakil hatlarına benzer şekilde trafo merkezlerine uzaklıkta (K7) da RES'lerin kurulum yeri seçiminde önemli bir kriterdir. Enerji iletimi sırasındaki kayıplar da göz önüne alındığında RES'lerin trafo merkezlerine yakın olması enerji verimliliği açısından büyük önem arz etmektedir. (Heimiller \& Haymes, 2001).

\subsubsection{Topoğrafik kriterler}

RES'lerin kurulacağı yerlerin seçiminde arazi kullanımın (K6) da rolü vardır. Özellikle yerleşim alanları (K8), yeşil alanlar ve su alanları RES yapımı için uygun değildir. Topoğrafyanın yapısı da RES kurma alanları için değerlendirilmesi gereken önemli bir kriterdir. Yükseklik (K3) ve eğim (K4) gibi topoğrafik kriterlere çalışmada yer verilmiştir. Düz arazinin, yüksek eğimli alanlarda ihtiyaç duyulan yüksek yatırım maliyetlerinden kaçınmaya yardımcı olacağını bilinmektedir. Rüzgâr hızı da yükseklikle orantılı biçimde artmaktadır. (Bennui ve ark, 2007).

\subsubsection{Cevresel kriterler}

Kültür varlıkları, tabiat varlıkları, yabani hayatı koruma ve geliștirme sahaları ve milli parklar koruma alanları (K12) olarak değerlendirilmektedir. $\mathrm{Bu}$ alanlar RES yapımı için uygun olmayan alanlardır. Literatürde korunan alanlara en az 500 m uzakta RES yapımı için uygunluk görülmektedir. Su alanları da 
(K11) rüzgâr tribünlerinin kurulumu için uygun olmayan alanlar arasındadır. Güvenlik açısından havaalanlarına da en az $3 \mathrm{~km}$ uzaklıkta bulunması gerekmektedir (Bennui ve ark, 2007).

\subsection{Rüzgâr Enerji Santrallerinin Yer Seçimine Etki Eden Kriterlerin AHP Yardımıyla Ağırlıklandırılması}

AHP yöntemi kullanılarak yer seçiminin yapılabilmesi için belirlenen kriterlere göre hiyerarşik yapı oluşturulmuştur. AHP karmaşık karar verme problemlerini çözmek için kriterlerin birbirine göre ilişkisini analiz eden bir tekniktir. Kriterlerin ağırlıklarını belirlemek için ilk olarak uzmanlar tarafindan doldurulan ikili karşılaştırma matrisleri oluşturulmuştur. Belirlenen kriterlerin birbirlerine göre önemleri 1 ile 9 arasında puanlanarak hesaplama matrisleri oluşturulur. Oluşturulan matrisin her sütunundaki değer sütun toplamına bölünerek matris normalize edilmiş ve normalizasyon matrisi oluşturulmuştur. $\mathrm{Bu}$ çalışmada 12 kriter belirlenmiş olup 4 uzman tarafından ikili karşılaştırma yöntemi ile karar matrisleri oluşturulmuştur. Karar vericiler tarafindan oluşturulan karar matrislerinin geometrik ortalaması alınmış ve daha sonra bu matris normalize edilerek normalizasyon matrisi oluşturulmuş ve bu işlem sonrası kriter ağırlıkları belirlenmiştir (Tablo 3).

Karar vericiler tarafından olușturulan ikili karşılaştırma matrislerinin kendi içerisindeki denetimi tutarlılık oranı hesaplanarak kontrol edilmiştir. İnsan hatasına dayalı olası tutarsızlı̆ı önlemek için, çeşitli benzer çalışmalarda kullanılan tutarlılık oranı (CR) kullanılmıştır. Tutarlılık oranını hesaplamak için İkili karşılaştırma matrisinin tutarlılık indeksi (CI) 0.13, tutarlılık oranı endeksi (CR) ise 0.08 olarak hesaplanmıştır. İkili karşılaştırma matrislerinin, tutarlılık oranı 0,1'den düşük olduğu için uygun kabul edilmiştir.

RES 'lerin yer seçimi için belirlenen kriterlerin hesaplanan ağılıkları Tablo 3'te gösterilmiştir. Tabloda görüldüğü üzere kriter sıralamasında ilk iki sırada rüzgâr hızı (\%23) ve rüzgâr kapasitesi (\%17) gelmektedir. Daha sonra en önemli kriter \%14 ile yükseklik kriteridir. Bunu \%11 ile arazi kullanım kriteri izlemektedir. Altyapı kriterlerinden olan enerji nakil hatlarına uzaklık, trafo merkezlerine uzaklık ve topoğrafik kriterlerden eğim kriteri \%6'llk eşit önem derecesine sahiptir.

\subsection{Rüzgâr Enerji Santrallerinin Yer Seçimine Etki Eden Konumsal Faktörlerin CBS ve AHP Yardımıyla Analizi}

$\mathrm{Bu}$ çalışmada Kayseri ili sınırları içerisinde rüzgâr enerji santralleri kurulumu için uygun alanların tespiti gerçekleștirilmiştir. Hazırlanan veriler ve yapılan analizlerin tümü ArcGIS 10.4 programı kullanılarak yapılmıștır.
Belirlenen kriterlerden yerleşim merkezlerine, korunacak alanlara, yüzey sularına, enerji nakil hatlarına, trafo merkezlerine, havaalanına ve ana yollara olan uzaklıklar "Euclidian Distance" yöntemiyle, raster veri șekline dönüștürülmüştür. Euclidean Distance, vektör verilerle veya raster verilerle yaptığınız analiz sonucunda, elinizdeki detaylara olan uzaklığı ölçüp çıktı olarak, her bir hücresinde yani pikselinde sizin kaynak verinize olan uzaklığı değer olarak saklayan bir raster katman oluşturur. Çalışmada kullanılan bu veriler uzaklıklarına göre yeniden sınıflandırılmış ve raster haritaları elde edilmiștir (Şekil 5). Elde edilen bu haritalar Kayseri il sınırlarından kesilmiștir. Öklid mesafesi (Euclidean Distance) işlemi sonrasında elde edilen veriler raster formatında olduğu için yeniden sınıflandırma (reclassify) işlemi uygulanabilmektedir. Arazi kullanım kabiliyeti, rüzgâr hızı, rüzgâr kapasitesi, eğim, yükseklik verileri için mesafeye ihtiyaç duyulmadığından öklid mesafesi (Euclidean Distance) uygulanmamış, sadece yeniden sinıflandırma (reclassify) işlemi uygulanmıştır. Şekil 5 'te görüldüğü gibi RES yer seçimine etki eden konumsal faktörler mesafeye göre puanlandırılmıştır. Tablo 3'te yer alan kıstaslara göre atanan uygunluk sınıfları da şu şekilde belirlenmiştir; uygun değil (0), çok uygun (1), uygun (2), orta derecede uygun (3) az uygun (4), çok az uygun (5) (Tablo 3).

ArcGIS yazılımında belirlenen 12 kriter ve Tablo 3'te gösterilen sinıflara göre haritalar oluşturulmuștur (Șekil 5). CBS analizleri ile elde edilen yeniden sınıflandırma haritaları ve AHP yöntemi ile belirlenmiş olan kriter ağırlıkları ArcGIS ortamında "Weighted Overlay" yöntemi ile birleştirilerek çakıştırılmış ve sonuç haritası elde edilmiştir (Şekil 6). Ağırlıklı bindirme (weighted overlay) aracı uygun alanın seçiminde çok kriterli sorunları çözmek için kullanılan yaklaşımlardan biridir. Kriter haritaları ağırlıklar ile çarpılır ve sonra üst üste çakıştırılarak sonuç haritası elde edilir. Bu çalışmada da Şekil 5'te elde edilen kriter sinıflandırma haritaları ağırlıklı bindirme yöntemi ile üst üste çakıştırılmış ve Kayseri ili için RES uygunluk haritası oluşturulmuştur (Şekil 7).

Elde edilen potansiyel alanlar alan bazlı olarak hesaplanmış ve son olarak çalışmanın denetimi açısından Kayseri'de mevcut durumda kullanımda olan rüzgâr enerji santrallerinin konumları elde edilen uygunluk haritası ile çakıştırılmış ve sonuçlar bölümünde yorumlanmıștır. 
Tablo 3. Seçilen Değerlendirme Kriterlerinin Uygunluk Sınıfları ve Ağırlık

\begin{tabular}{|c|c|c|c|c|c|c|c|c|}
\hline \multirow[b]{2}{*}{ Kriterler } & \multirow[b]{2}{*}{ Birim } & \multirow[b]{2}{*}{ Ăgırlıklar } & \multicolumn{6}{|c|}{ Uygunluk sınıfları ve değer aralıkları } \\
\hline & & & $\begin{array}{c}\text { Çok uygun } \\
\text { (1) }\end{array}$ & $\begin{array}{l}\text { Uygun } \\
\text { (2) }\end{array}$ & $\begin{array}{c}\text { Orta derece } \\
\text { uygun (3) }\end{array}$ & $\begin{array}{c}\text { Az uygun } \\
\text { (4) }\end{array}$ & $\begin{array}{c}\text { Çok az uygun } \\
\text { (5) }\end{array}$ & $\begin{array}{c}\text { Uygun değil } \\
\text { (0) }\end{array}$ \\
\hline Rüzgâr Hızı (K1) & $\mathrm{m} / \mathrm{s}$ & 23 & $9-10$ & 8- 9 & 7- 8 & $6.5-7$ & - & $3.5-6.5$ \\
\hline $\begin{array}{l}\text { Rüzgâr Kapasitesi } \\
\text { (K2) }\end{array}$ & $\%$ & 17 & $50-60$ & $40-50$ & 35- 40 & $25-35$ & $11-11.7$ & $10-25$ \\
\hline Yükseklik (K3) & $\mathrm{m}$ & 14 & $1100-1750$ & $\begin{array}{l}1000-1100 \\
1750-2250 \\
\end{array}$ & $2250-2750$ & - & - & $\begin{array}{l}0-1000 \\
>2750\end{array}$ \\
\hline Eğim (K4) & $\%$ & 6 & $0-5$ & $5-10$ & $10-13$ & $13-16$ & $16-20$ & $>20$ \\
\hline $\begin{array}{l}\text { Ana Yola } \\
\text { Uzaklık (K5) }\end{array}$ & $\mathrm{m}$ & 4 & $100-1000$ & $1000-1500$ & $1500-2500$ & $2500-3500$ & $>3500$ & $0-100$ \\
\hline Arazi Kullanımı (K6) & - & 11 & Kayalık & $\begin{array}{l}\text { Tarımsal } \\
\text { alan }\end{array}$ & - & - & - & $\begin{array}{c}\text { Yeşil alan, } \\
\text { Yerleşim, Su }\end{array}$ \\
\hline $\begin{array}{l}\text { Trafo Merkezlerine } \\
\text { Uzaklık (K7) }\end{array}$ & $\mathrm{m}$ & 6 & $0-1000$ & $2500-3500$ & 5000- 10000 & $10000-15000$ & $15000-25000$ & $>25000$ \\
\hline $\begin{array}{l}\text { Yerleşim Merkezine } \\
\text { Uzaklık (K8) }\end{array}$ & $\mathrm{m}$ & 3 & $>5000$ & $2000-2500$ & $2000-2500$ & $1500-2000$ & 500- 1500 & $0-500$ \\
\hline $\begin{array}{l}\text { Enerji Nakil Hatlarına } \\
\text { Uzaklık (K9) }\end{array}$ & - & 6 & $0-100$ & $100-500$ & 500- 1000 & $1000-2500$ & $2500-5000$ & $>5000$ \\
\hline $\begin{array}{l}\text { Havaalanına } \\
\text { Uzaklık (K10) }\end{array}$ & $\mathrm{m}$ & 3 & $>3000$ & - & - & - & - & $0-3000$ \\
\hline $\begin{array}{l}\text { Yüzey Sularına } \\
\text { Uzaklık (K11) }\end{array}$ & $\mathrm{m}$ & 3 & $>7500$ & $5000-7500$ & $2500-5000$ & $1000-2500$ & 500- 1000 & $0-500$ \\
\hline $\begin{array}{l}\text { Korunan } \\
\text { Alanlara Uzaklık } \\
\text { (K12) }\end{array}$ & $\mathrm{m}$ & 4 & $>7500$ & $5000-7500$ & $2500-5000$ & $1000-2500$ & 500- 1000 & $0-500$ \\
\hline
\end{tabular}



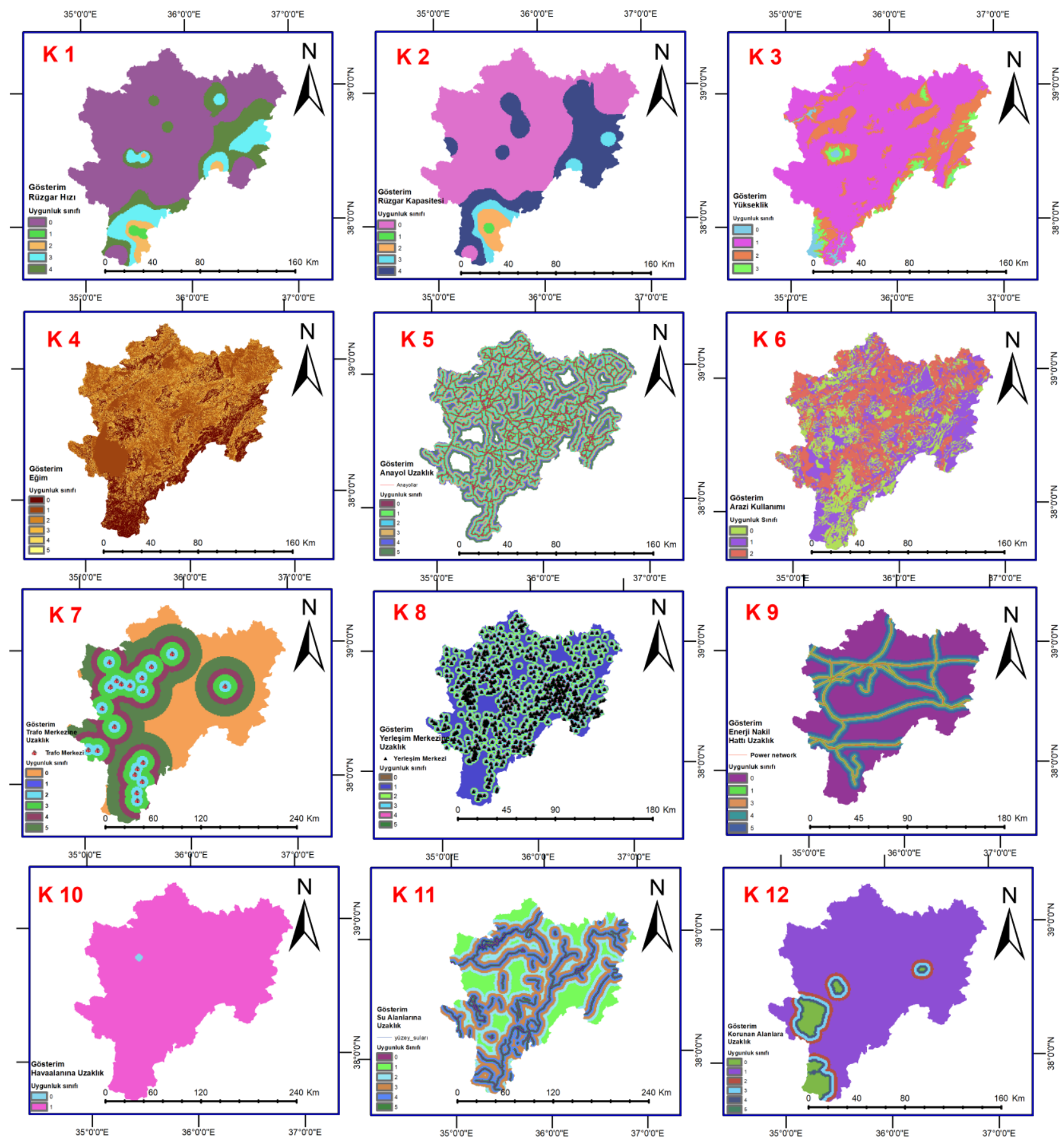

Şekil 5. 12 Kriter İçin Yeniden Sınıflandırılmış Haritalar *

* K1 Rüzgar hızı, K2 Rüzgar kapasitesi, K3 Yükseklik, K4 Eğim, K5 Anayola uzaklık, K6 Arazi kulanımı, K7 Trafo merkezine uzaklık,, K8 Yerleșim merkezine uzaklık, K9 Enerji nakil hatlarına uzaklık, K10 Havaalanına Uzaklık, K11 Yüzey sularına uzaklık, K12 Korunan alanlara uzaklık. 


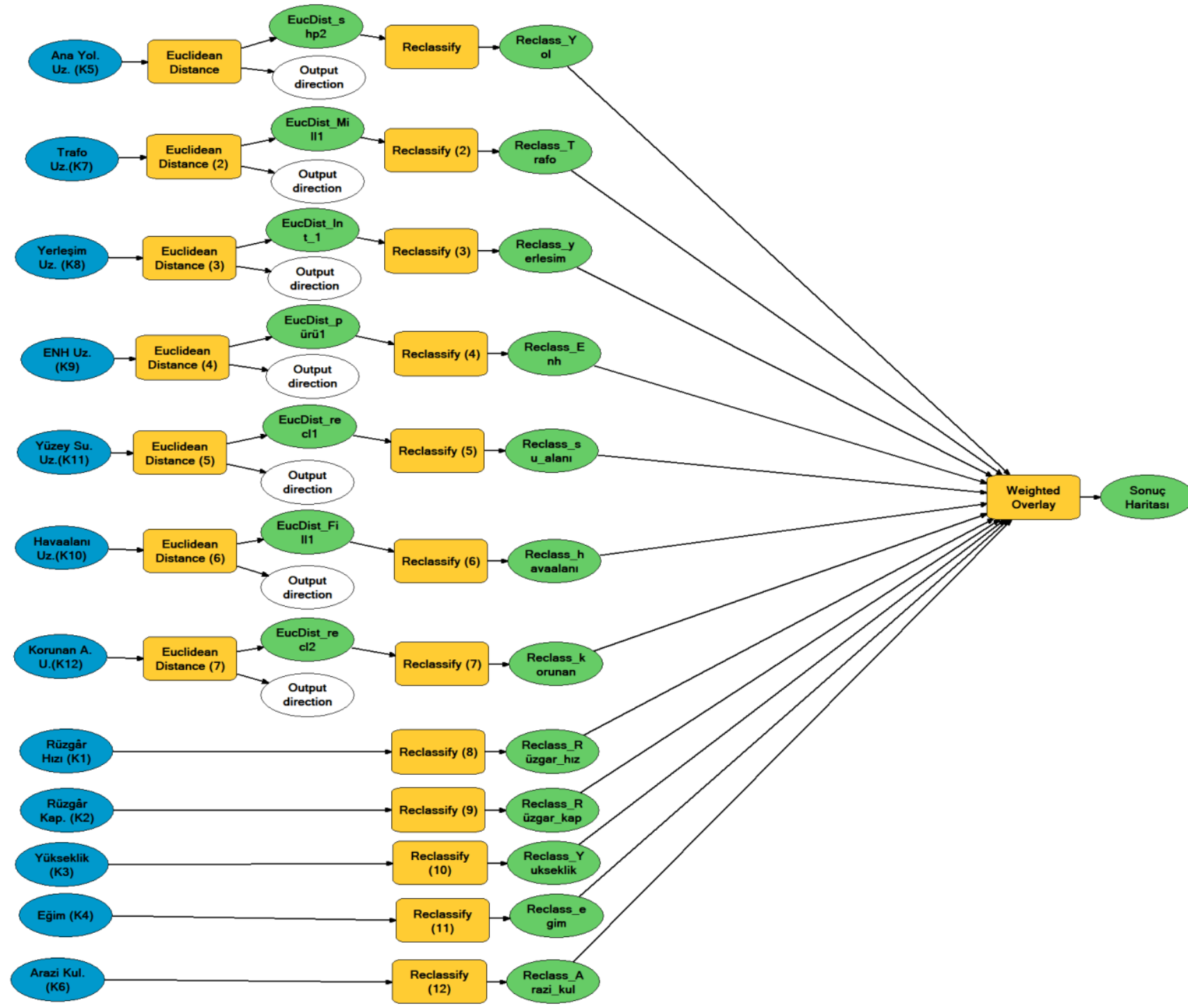

Şekil 6. RES Yer Seçimi İşlemi İçin Hazırlanan Model

\section{TARTIŞMA VE SONUÇLAR}

Bu çalıșmada rüzgâr enerji santralleri için yer seçimi sürecinin hangi aşamalardan oluştuğu irdelenmiş, yer seçimi için belirlenen kriterlerin uygunluk haritaları elde edilmiş, AHP yöntemi kullanılarak bu kriterler ağırlıklandırılmıș ve sonuçta Kayseri ili için RES alanı uygunluk haritası elde edilmiştir.

Nihai uygunluk haritası (Şekil7), gösterim kısmında gösterildiği gibi "0 uygun değil", "1 çok uygun", "2 uygun", "3 az uygun" olarak dört sinıf olarak çıkmıştır. Bu haritadan bölgenin 0,652 $\mathrm{km}^{2}$ sinin yüksek derecede uygun olduğu, 0,892 $\mathrm{km}^{2}$ lik alanın rüzgâr santrali için orta derecede uygun olduğu, son olarak bölgenin $162 \mathrm{~km}^{2}$ lik kısmının az uygun sınıfa düștüğ̈̈ görülmüștür. Belirlenen kriterlere göre uygun olmayan alan, çalışma alanının $16852 \mathrm{~km}^{2}$ 'lik kısmını oluşturmakta olup, potansiyelin yüksek olduğu alanlar esas olarak şehrin güney ve doğu bölgelerinde bulunan ilçeleri Yahyalı ve Pınarbaşı'nda görülmüş̧ür. Mevcut bulunan lisanslı santral yerleri veya henüz inşa halinde olan alanlar daha çok Yahyalı ilçesinde bulunmaktadır.

Çıkan sonuç haritası, mevcut durumda kullanımda olan rüzgâr santralleri konum verisi ile çakıştırıldığında, santrallerin çalışmamızda belirlemiş olduğumuz uygun olmayan alanların dışında olduğu, hatta büyük bir bölümünün puanlandırmada en uygun olarak belirlenen sınıfa düştüğü görülmüştür.

Bu sonuçlar çalıșmada uygulanan AHP ve CBS analizleri ile yer seçimi metodunun makul ve uygulanabilir olduğunu göstermiștir (Șekil 7). Ayrıca elde edilen potansiyel alanlar Türkiye Rüzgâr Enerjisi Potansiyel Atlası (REPA) ile karşılaștırıldığında sonuçların birbirine yakın olduğu görülmüştür. 


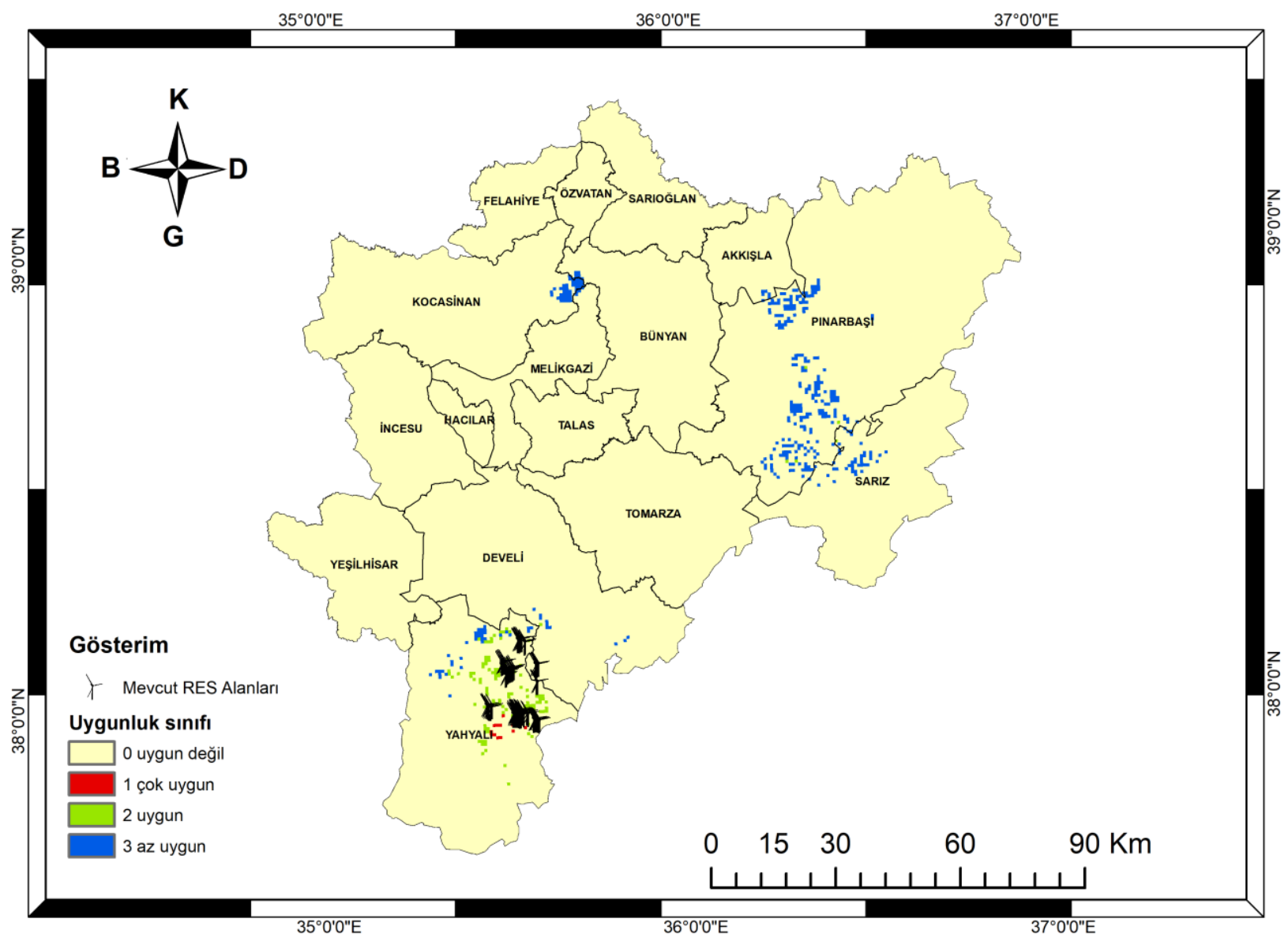

Şekil 7. Kayseri İli RES Alanı Uygunluk Haritası

$\mathrm{Bu}$ çalışmanın çevresel, sosyo-kültürel ve ekonomik açıdan etkilerini inceleyecek olursak; korunan alanlar kriteri ile Kayseri ilindeki milli parklar santral yerleri için uygun olmayan sınıfa atanmış ve bu alanların korunması sağlanmıştır. Arazi kullanım kriteri ile verimli tarım alanları ve yeșil alanlar da yine uygun olmayan sınıfa atanarak bu alanların korunması sağlanmışıı. Irmak, nehir ve göl alanları da su alanlarına uzaklık kriteri dikkate alınarak analiz edilmiş ve bu alanlarında RES için uygun olmayan alanlar sınıfına alınarak korunması sağlanmıştır. Rüzgâr türbinlerinde oluşabilecek en önemli çevresel sorun gürültü olarak değerlendirilmektedir. Bu sebeple, rüzgâr enerjisi santralleri yerleşim yerinin olmadığı ya da yükselti farklılıklarından dolayı gürültünün çok az hissedildiği yerlere inşa edilmektedir. Çalışmamızda yerleşim yerlerine uzaklık kriteri göz ününe alınmış ve yerleşim bölgelerinden uzak alanlar uygun alan olarak seçilmiştir. Yapılan bu çalışma ile rüzgâr enerjisinden alınan verimin artması da ülke ekonomisine daha fazla katkı sağlanmasını mümkün kılacaktır. Sonuç olarak potansiyeli yüksek alanlara yapılan doğru yatırımlar sayesinde hem ekonomik hem çevresel hem de sosyo-ekonomik açıdan olumlu etkilerin olacağı öngörülmektedir.

Kayseri ili kapsamında rüzgâr enerjisi için var olan bu potansiyelin kullanılıp, en ekonomik en verimli șekilde değerlendirilmesi gerekmektedir. $\mathrm{Bu}$ çalışma ile RES yer seçim sürecinde; doğru yatırımların yapılabilmesi, CBS ve AHP yardımıyla doğru alanların tespit edilmesi yönüyle literatüre katkı sağlamıştır. CBS ve AHP yöntemleri kullanılarak yapılan bu çalışma, benzer sahalar içinde aynı yöntemin kullanılabileceğini göstermekte olup gelecekte kurulacak RES projeleri için yol gösterici olacaktır.

\section{BILGILENDIRME/TEŞEKKÜR}

Çalıșmam süresince, veri paylașımı konusunda desteklerinden dolayı Kayseri Büyükșehir Belediyesine teșekkürlerimi sunarım.

\section{ARAŞTIRMACILARIN KATKI ORANI}

Tuğrul Urfalı: Veri toplama, Araştırma, Makale yazma; Abdurrahman Eymen: Araştırma, Makale yazma, Düzenleme

\section{ÇATIŞMA BEYANI}

Herhangi bir çıkar çatışması bulunmamaktadır.

\section{KAYNAKÇA}

Atici, K. B., Simsek, A. B., Ulucan, A., \& Tosun, M. U. (2015,). A GIS-based Multiple Criteria Decision Analysis approach for wind power plant site selection. Utilities Policy, 37, 86-96. 
Ayodele, T. R., Ogunjuyigbe, A. S., Odigie, O., \& Munda, J. L. (2018). A multi-criteria GIS based model for wind farm site selection using interval type-2 fuzzy analytic hierarchy process: The case study of Nigeria,. Applied Energy, 228, 1853-1869.

Baban, S. M. J., Parry, T., (2001). Developing And Applying A GIS-Assisted Approach To Locating Wind Farms In The UK, Renewable Energy, 24, 59-71.

Bennui, A., Rattanamanee, P., Puetpaiboon, U., Phukpattaranont, P., \& Chetpattananondh, K. (2007). Site Selection For Large Wind Turbine Using GIS. PSU-UNS International Conference on Engineering and Environment, (s. 561-566). Phuket:ICEE.

Can, G., \& Yücel, M. A. (2019). Coğrafi Bilgi Sistemleri ve Analitik Hiyerarşi Prosesi Kullanarak Rüzgar Enerji Santralleri İçin Yer Tespiti. TMMOB Harita ve Kadastro Mühendisleri Odası, 17. Türkiye Harita Bilimsel ve Teknik Kurultayı. 25-27 Nisan, Ankara.

Çildir, M., \& Bayraç, H. (2017). AB Yenilenebilir Enerji Politikalarının Ekonomik Büyüme Üzerindeki Etkisi. International Journal of Management Economics and Business. 13. 10.17130/ijmeb.2017ICMEB1735446.

Haliloğlu, M., \& Odabaş, M. S. (2018). Çok ölçütlü karar vermede ahp yöntemi. Kilis 7 Aralık Üniversitesi Fen ve Mühendislik Dergisi, 2(2), 1318.

Heimiller, D. M., \& Haymes, S. R. (2001). Geographic Information Systems in Support of Wind Energy Activities at NRE. 39th AIAA Aerospace Sciences Meeting Reno. Nevada.

Elektrikport,(2020) URL-4: 25.06.2020 tarihinde Elektrikport.com Web Sayfası: (https://www.elektrikport.com/haberroportaj/2019-yili-turkiye-elektrikistatistikleri/22488\#ad-image-0) adresinden alındı.

IEA Int Energy Agency (2017). Agency for Natural

Resources and Energy. Key World Energy statistics.doi:10.1017/CB09781107415324.004.

Latinopoulos, D., \& Kechagia, K. (2015). A GIS-based multi-criteria evaluation for wind farm site selection. A regional scale application in Greece. Renewable Energy, 78, 550-560.

Memduhoğlu, A., Özmen, G., Göyçek, G., \& Kılıç, F. (2014). Rüzgar Türbini Kurulacak Alanların CBS Çok Ölçütlü Karar Analizi Kullanılarak Belirlenmesi Davutpaşa Kampüsü . 5. Uzaktan Algılama Ve Coğrafi Bilgi Sistemleri Sempozyumu, 14 Ekim 2014, s. 1. İstanbul.

Messaoudi, D., Settou, N., Negrou, B., \& Rahmouni, S. (2018). Site Selection Methodology For The Wind-Powered Hydrogen Refuelig Statin Based On AHP-GIS in Adrar, Algeria. Energy Procedia, 162, 67-76.
Özşahin, E., \& Kaymaz, Ç. (2013). Rüzgâr Enerji Santrallerinin (Res) Yapım Yeri Seçimi Üzerine Bir Cbs Analizi: Hatay Örneği. Türk Bilim Araștırma Vakfi Bilim Dergisi, 1-18.

Öztürk, D., \& Kılıç, F. (2010). Konumsal karar verme problemlerinde analitik hiyerarşi yönteminin kullanılması. Journal of Engineering and Natural Sciences Mühendislik ve Fen Bilimleri Dergisi, 28, 124-137.

Sadeghi, M., \& Karimi, M. (2017). GIS-Based Solar and Wind Turbine Site Selection Using Multi-Criteria Analysis: Case Study Tehran, Iran. ISPRS International Archives of the Photogrammetry, Remote Sensing and Spatial Information Sciences.XLII-4/W4. 469-476. 10.5194/isprsarchives-XLII-4-W4-469-2017. Tahran.

Said, S. M., Akil, Y. S., \& Muzakir, M. H. (2019). GIS approach for wind power plant development in South Sulawesi, Indonesia: A location suitability analysis. AIP Conference Proceedings, 2097.30085.10.1063/1.5098260.

Şimşek, A. B. (2014). Coğrafi Bilgi Sistemleri Tabanlı Çok Kriterli Karar Analizinin Rüzgar Türbini Yer Seçim Probleminde Uygulanması. Hacettepe Üniversitesi Sosyal Bilimler Enstitüsü.

TEIAŞ. (2019). URL-3 05.04.2020 tarihinde https://www.teias.gov.tr/tr/elektrikistatistikleri adresinden alındı.

T.C. Kültür ve Turizm Bakanlığı (2020). URL-5 05.04.2020 tarihinde https://kayseri.ktb.gov.tr/TR-54966/cografiyapi.htmlistatistikleri adresinden alınd..

TUREB. (2018). URL-2 14.05.2020 tarihinde https://www.tureb.com.tr/files/tureb_sayfa/du yurular/2018/03/turkiye_ruzgar_enerjisi_istatis tik_raporu_ocak_2018.pdf adresinden alınd.

Uyan, M. (2013). GIS-based solar farms site selection using analytic hierarchy process (AHP) in Karapinar region, Konya/Turkey. Renewable and Sustainable Energy Reviews, 28, 11-17.

Vaysman, Y., Surkov, A., Surkova, Y., Vlasov, A., \& Kychkin, A. (2019). Methodology to Evaluate the Placement of Wind Turbine Based on GIS Technology. IOP Conference Series: Earth and Environmental Science, 317. 012001. 10.1088/1755-1315/317/1/012001.

Villacreses, G., Gaona, G., Martínez, J., \& Jijón , D. (2017). Wind farms suitability location using geographical information system (GIS), based on multi-criteria decision making (MCDM) methods: The case of continental Ecuador. Renewable Energy, 109, 275-286.

YEGM. (2019). URL-1: 28.02.2019 tarihinde Yenilenebilir Enerji Genel Müdürlüğü, Kayseri İli Rüzgâr Kaynak Bilgileri: Web Sayfası: (http://www.yegm.gov.tr/YEKrepa/KAYSERIREPA.pdf). adresinden alındı 